\title{
" 乙UDO É E NÃO É”: PARADOXOS E ANTINOMIAS NO PENSAMENTO DE RIOBALDO E NO IMAGINÁRIO DE VIOLEIROS DO VALE do São Francisco, NORTE de Minas Gerais
}

\author{
Wagner Neves Diniz Chaves \\ Universidade Federal do Rio de Janeiro \\ Rio de Janeiro - RJ - Brasil \\ Orcid: https://orcid.org/0000-0003-0479-4445
}

Introdução

Natureza da gente não cabe nenhuma certeza.

(Riobaldo)

Tendo como um de seus grandes temas o humano, em sua faceta inacabada, ambígua e antagônica, Guimarães Rosa, em seu romance Grande Sertão: Veredas, nos convida, leitores, a um mergulho no imaginário do ex-jagunço Riobaldo, narrador e personagem central da obra literária. Não muito afeito a um pensar linear e acabado, Riobaldo, que é conhecido no meio da jagunçagem como Tatarana (ou "lagarta de fogo") em referência a sua pontaria, parece personificar uma filosofia paradoxal, uma "ambiguidade metafísica" (Candido 1964), em que "tudo é e não é". Suas certezas, sempre provisórias, são atravessadas por questionamentos, dúvidas e soluções antinômicas.

Riobaldo aparece, ao longo de toda a obra, da primeira à última página, como marcado por um questionamento crucial: o diabo existe ou não existe? Esse dilema existencial, que acompanha o personagem, todavia, não tem uma solução definitiva. A 
resposta dele parece repousar na inquietação e no labirinto de incertezas - "Será não? Será?", "Pois não sim!". Em tal pensar, as posições não estão definidas ou estabilizadas: as coisas podem ser e deixar de ser, em um constante processo de transformação e inacabamento. A verdade não é concebida como lócus da ordenação e da certeza, mas, ao contrário, se existe alguma, é a verdade da travessia, do devir e do movimento. Tudo, em certo sentido, está em relação ou potencialmente pode se misturar - bem e mal, natural e sobrenatural, homem e mulher, vivos e mortos, sertão e civilização, progresso e atraso, deus e diabo, esse mundo e outro mundo, guerra e paz, etc. Nesse pensar, os pastos, como faz questão de lembrar Riobaldo, não estão definitivamente demarcados.

Ao dar visibilidade aos discursos provenientes das margens e zonas liminares, evidenciando as indefinições, ambiguidades e fluidez do real, Grande Sertão é um campo aberto de possibilidades, servindo como inspiração para vislumbrarmos muitas conexões com o contexto etnográfico do sertão mineiro. Tendo como hipótese de fundo a ideia de que Riobaldo revela uma filosofia da mistura, dos paradoxos e antinomias, em que "tudo é e não é", este artigo pretende, por um lado, descrever como tal percepção de mundo é construída a partir dos questionamentos do personagem acerca da existência ou não do diabo e, por outro, observar como esse imaginário está presente entre os violeiros do vale do São Francisco, onde realizo pesquisas etnográficas desde 2002. Nesse exercício relacional, o dilema da existência ou não do diabo, que ocupa as preocupações de Riobaldo, será comparativamente confrontado com a ambivalência simbólica da viola, associada pelos violeiros tanto a Jesus e aos Reis Magos quanto ao próprio demônio ${ }^{1}$.

A conversa entre literatura e antropologia que me inspira, desse modo, não implica nem a busca pelas dimensões e potencialidades "literárias" (ou poéticas) dos textos etnográficos (Laplantine 2003; Osório e Prado 2015) ou etnográficas dos literários (DaMatta 1993), nem analisar as estratégias de construção de autoridade narrativa e discursiva presentes na escrita etnográfica (Marcus \& Cushman 1982; Clifford \& Marcus 1986). Também não busco sublinhar as particularidades de cada área, evidenciando as diferenças de natureza teórica, epistemológica e retórica que as separam.

O mergulho no texto literário e sua aproximação com a antropologia como aqui proponho, diferentemente, procura correspondências e entrelaçamentos de problemáticas e abordagens e de exploração das complementaridades e das zonas fronteiriças, dos atravessamentos e passagens que veiculam esses campos (Palmeira e Carneiro 2013). Como em um jogo de espelhamentos, o texto literário torna-se um modo de conhecimento, oferecendo uma perspectiva boa para pensarmos determinadas questões etnográficas².

\section{Sertão e civilização entre mundos}

"Olhe: o que devia de haver, era de se reunirem-se os sábios, políticos, constituições gradas, fecharem o definitivo a noção - proclamar por uma vez, artes assembleias, 
que não tem diabo nenhum, não existe, não pode. Valor de lei! Só assim, davam tranquilidade boa à gente. Por que o Governo não cuida?!” (:14)³. Nessa passagem, Riobaldo, dirigindo-se ao leitor-ouvinte, clama ao Governo que atue, reúna sábios e políticos para resolver de uma vez por todas a dúvida a respeito da existência ou não do diabo. Constituições e leis seriam então criadas e firmadas para dar o definitivo da questão. Esse mundo de certezas e convicções idealizado e projetado por Riobaldo ("o que deveria ser"), onde reinaria a tranquilidade, não é definitivamente o mundo no qual ele se move. O narrador, ao mesmo tempo que constata a não atuação do Governo, questiona-se sobre as razões dessa ausência. Perceber o duplo sentido do enunciado "Por que o governo não cuida?!", que pode ser lido tanto como uma afirmação ("porque o governo não cuida") quanto como uma pergunta ("por que o governo não cuida?").

Essa passagem levanta uma questão fundamental e que perpassa toda a obra: a existência, no Brasil de um profundo abismo separando, de um lado, o governo, a ordem e a lei - representadas pelo ouvinte letrado, que é o próprio Guimarães Rosa ("o jovem doutor da cidade" para quem Riobaldo narra suas memórias) e por nós leitores - e, de outro lado, o sertão, interior, lugar do perigo, da ausência do Estado e onde proliferam o jaguncismo, a violência e os mais variados (des)mandos.

Nesse espelhamento de posições na trama narrativa, se o lugar do ouvinte está mais ou menos definido, o mesmo não pode ser dito com relação ao narrador. Ocupando uma posição paradoxal - ex-jagunço e chefe de bando, ele também foi professor e, atualmente, quando relata suas memórias, é um bem-sucedido fazendeiro -, Riobaldo é um personagem das margens, assumindo uma posição "liminar" (Turner 2013 [1969]) de mediação entre mundos, sendo a própria personificação das contradições e paradoxos dessa instável condição de (não) ser sertanejo e (nem) civilizado e de viver atormentado pela dúvida a respeito do diabo e do pacto 4 .

Riobaldo, ao mesmo tempo que evoca a conhecida imagem do sertão como lócus da ausência, constatando a existência do abismo que o separa de um "outro", representado pelo governo, pelos sábios e políticos, esforça-se em estabelecer contato e comunicação entre esses mundos. Nessa direção é que entendo sua posição ao implorar a esse "outro" que estabeleça, de uma vez por todas, com a força e o poder da lei, a não existência do diabo 5 .

Posição essa que, diga-se de passagem, também é defendida por outro personagem do Grande Sertão: Zé Bebelo. Retratado como um típico coronel, fazendeiro e aspirante a político, ele tem uma ambição - transformar, civilizar o sertão, "levando o progresso ao norte". Para alcançar tal feito, todavia, precisa acabar com o atraso, representado pelo jaguncismo, do qual, paradoxalmente, ele próprio se torna no decorrer da narrativa um dos maiores representantes quando passa a ocupar a chefia de um bando ${ }^{6}$.

Riobaldo assim se refere às intenções civilizatórias de Zé Bebelo, com quem sempre manteve uma relação de respeito e admiração: "depois que abolice o jaguncismo e deputado fosse, então reluzia perfeito o norte, botando pontes, baseando fábricas, remediando a saúde de todos, preenchendo a pobreza, estreando mil escolas" (:122). 


\section{Deus e o Diabo nas veredas do "Grande Sertão"}

"Eu quase que nada não sei. Mas desconfio de muita coisa. O senhor concedendo eu digo: para pensar longe sou cão mestre - o senhor solte em minha frente uma ideia ligeira, e eu rastreio essa por fundo de todos os matos, amém!" (:14). Espaço simbólico, onde o "pensamento da gente se forma mais forte do que o poder do lugar" (:24), o sertão em Rosa não se assenta em uma base física, territorial ou geográfica. Para além de um lugar, o sertão roseano é um campo aberto. Em tal universo, inacabado, as definições e certezas são provisórias, transformam-se. Afinal de contas, como não se cansa de questionar Riobaldo ao longo de toda a obra, "Viver nem não é muito perigoso?".

Nesse pensar, em que os pastos não estão definitivamente demarcados, os contrários e os opostos convivem entre si e, às vezes, não raro, se misturam, se fundem. Como esclarece o personagem, a ilusão maior - e que também define o humano - é tentar dar forma as coisas, lhes emprestar sentidos fixos:

Baixei, mas fui ponteando opostos. Que isso foi o que sempre me invocou, o senhor sabe: eu careço de que o bom seja bom e o ruim ruim, que dum lado esteja o preto e do outro o branco, que o feio fique bem apartado do bonito e a alegria longe da tristeza! Quero todos os pastos demarcados... Como é que posso com este mundo? A vida é ingrata no macio de si; mas tanstraz a esperança mesmo do meio do fel do desespero. Ao que, este mundo é muito misturado... (:206-207).

A mensagem de Riobaldo parece ser a de que, se existe alguma verdade, é a verdade da travessia: "O real não está na saída nem na chegada; ele se dispõe para a gente é no meio da travessia" (:60), ou ainda "No real da vida, as coisas acabam com menos formato, nem acabam" (:79). No mundo, no real da vida, tudo está ou potencialmente pode se misturar, mas o ser humano se esforça em separar, dar forma e acabamento às coisas. Daí o embate, o conflito e a culpa. Riobaldo, desse modo, encarna dilemas existenciais profundos. Dilemas esses que podem ser lidos como próprios da coexistência de mundos ou regimes de verdades distintos e tensionados: se, por um lado, o personagem representa um pensar fluido, da não demarcação dos pastos, em que tudo é e não é, das certezas relativas, da mistura, das antinomias e paradoxos; por outro, se vê diante de uma imensa dúvida-culpa por ter supostamente feito pacto com o diabo, culpa essa baseada em um dilema existencial forjado pelo antagonismo entre o bem e o mal?

Uma vez mais estamos aqui diante da questão crucial referente à ausência de diálogo, comunicação e entendimento entre mundos. Riobaldo, sertanejo, que percebe o movimento do real na mistura, na relatividade das formas e da verdade, perante uma mentalidade que busca verdades universais e, consequentemente, procura se 
distanciar das contradições, paradoxos, dúvidas e incertezas. Essa tensão entre mundos, que aparece ao longo de todo o texto, assume tons dramáticos nos questionamentos de Riobaldo sobre a existência ou não do diabo, assunto que atravessa toda a obra, da primeira à última linha.

A história começa com o som de tiros: "Nonada. Tiros que o senhor ouviu foram de briga de homem, Deus esteja". Riobaldo estava atirando no quintal, como de costume, quando vieram pedir a sua arma por causa de uma estranha figura que aparecera: "Causa dum bezerro: um bezerro branco, erroso, os olhos de nem ser - se viu -; e com máscara de cachorro". Ele nem quis avistar a figura - "cara de gente, cara de cão: determinaram - era o demo". Por fim, diante de um ouvinte-leitor estranho a esse mundo, que "ri certas rizadas", sentencia: "O senhor tolere, isso é o sertão" (:7).

A partir de então, a presença do mal, personificado no diabo, aparece como um dos grandes temas de Grande Sertão. Riobaldo se faz a pergunta inúmeras vezes. Quando vai responder, dúvidas e incertezas: "será não? Será?”, "Pois não sim!", “Tem diabo nenhum. E tem?!", "O diabo existe e não existe?". Ao se questionar sobre a existência ou não do diabo e se com ele contraiu ou não pacto, em nenhum momento parece resolver a questão. Muito ao contrário, o que ele frequentemente faz é cercá-la, rastreá-la, tornando-a ainda mais enigmática. Avesso ao pensamento linear, evitando tratar diretamente um problema, ele parece mais afeito a um caminhar enviesado, que rodeia e analisa a questão a partir de vários ângulos distintos: "O diabo existe e não existe? Dou o dito. Abrenúncio. Essas melancolias. O senhor vê: existe cachoeira; e pois? Mas a cachoeira é barranco de chão e água caindo por ele, retombando; o senhor consome essa água, ou desfaz o barranco, sobra cachoeira alguma?" (:9-10).

Nessa interessante passagem, Riobaldo, ao enfrentar a questão do diabo, traz a imagem de uma cachoeira cuja existência deriva de um emaranhado de coisas - água, terra, barranco. A cachoeira é tudo isso junto e misturado. $O$ mesmo se pode dizer do diabo? Que a sua existência está veiculada a tudo que ele articula e conecta? É possível algo existir mesmo sem acreditarmos?

O que existe é o que se apresenta. Riobaldo, um profundo conhecedor do ambiente natural em que vivia, com os seus rios e árvores, ventos e tempestades, plantas e animais, ao discorrer sobre as misturas, a inevitabilidade da copresença, aproximação e reversibilidade dos contrários, nos lembra o caso da mandioca:

Melhor, se arrepare: pois, num chão, e com igual formato de ramos e folhas, não dá a mandioca mansa, que se come comum, e a mandioca-brava, que mata? Agora, o senhor já viu uma estranhez? A mandioca-doce pode de repente virar azangada - motivos não sei; às vezes se diz que é por replantada no terreno sempre, com mudas seguidas de manaíbas vai se amargando, de tanto em tanto, de si mesma toma peçonhas. E, ora veja: a outra, mandioca-brava, é que também as vezes pode ficar mansa, a esmo, de se comer sem nenhum mal" (:10). 
A imagem da mandioca em transmutação, movimentando forças contrárias em sua existência, nos leva novamente aos embates entre o bem e o mal. Não tão separados assim na vida de um tubérculo como a mandioca, os contrários também não parecem apartados na vida dos humanos, mesmo quando deles procura afastar-se. Sobre o diabo, Riobaldo em determinado momento, dirigindo-se ao ouvinte-leitor, parece seguro da sua não existência: "E as idéias instruídas do senhor me fornecem paz. Principalmente a confirmação, que me deu, de que o Tal não existe"; ou "Agora, bem: não queria tocar nisso não mas - de o tinhoso; chega. Mas tem um porém: pergunto: o senhor acredita, acha fio de verdade nessa parlenda, de com o demônio se poder tratar pacto? Não, não é não? Sei que não há" (:23). Mas na sequência, a certeza vira dúvida: "pois não?". Riobaldo, então, apresenta um catálogo de nomes para designar o demo - "O Arrenegado, o Cão, o Cramulhão, o Indivíduo, o Galhardo, o Pé-de-Pato, o Sujo, o Homem, o Tisnado, o Coxo, o Temba, o Azarape, o CoisaRuim, o Mafarro, o Pé-Preto, o Canho, o Duba-Dubá, o Rapaz, o Tristonho, o Não-seiquediga, O-que-nunca-se-ri, o Sem-Gracejos" (:37) - para no fim sentenciar: "Pois, não existe!". No entanto, como não era mesmo muito afeito a certezas, novamente a clareza se turva e o que era afirmação vira pergunta: "E se não existe, como é que se pode se contratar pacto com ele?" (:37).

E a ideia do pacto se faz presente de novo. Riobaldo, ao se referir ao personagem Hermógenes, seu maior adversário nas batalhas da jagunçagem, em tom afirmativo diz: "o Hermógenes tem pauta... ele se quis como o Capiroto... eu ouvi aquilo demais. O pacto! Se diz - o senhor sabe"; ou "O Hermógenes tem pautas... Com ele ninguém podia? O Hermógenes - demônio. Sim só isto. Era ele mesmo” (:45).

O diabo, personificação do mal, não aparece como um ente, pessoa, mas como uma força que se esconde dentro de cada homem e, no limite, está misturado em tudo.

Tem diabo nenhum. Nem espírito. Nunca vi. Alguém devia de ver, então era eu mesmo, este vosso servidor. Fosse lhe contar... Bem, o diabo regula seu estado preto, nas criaturas, nas mulheres, nos homens. Até: nas crianças - eu digo. Pois não é ditado: "menino - trem do diabo?" E nos usos, nas plantas, nas águas, na terra, no vento... Estrumes... O diabo na rua, no meio do redemunho... (:10, grifo do autor).

Hermógenes, a própria personificação do mal ("homem sem anjo da guarda"), pactário e tendo a proteção do capeta, era praticamente invencível, a não ser que... e o que se desenhava acaba por acontecer. Riobaldo, não sem antes hesitar, finalmente decide ir a um local por nome Veredas-Mortas motivado a tomar o pacto para poder então enfrentar Hermógenes de igual para igual. Era de noitinha quando Riobaldo recebe "coragem de decisão". Nesse momento, ele parece não ter dúvida. Intimado, foi! Na hora chegada, mais precisamente no cair da tarde de um dia como tantos 
outros, Riobaldo se aparta dos seus companheiros e caminha rumo ao lugar por nome Veredas-Mortas. Passava da meia-noite quando Riobaldo relata o ocorrido:

Sapateei, então me assustando de que nem gota de nada sucedia, e a hora em vão passava. Então, ele não queria existir? Existisse. Viesse! Chegasse, para o desenlace desse passo. Digo direi, de verdade: eu estava bêbado de meu. Ah, esta vida, às não-vezes, é terrível bonita, horrorosamente, esta vida é grande. Remordi o ar:

- "Lúcifer! Lúcifer!..." - aí eu bramei, desengolindo.

Não. Nada. O que a noite tem é um vozeio de um ser-só - que principia feito grilo e estalinhos, e o sapo-cachorro, tão arranhão. E que termina em um queixume borbulhado tremido, de passarinho ninhante mal-acordado dum totalzinho sono.

- "Lúcifer! Satanás!..."

Só outro silêncio. O senhor sabe o que o silêncio é? É a gente mesmo, demais.

- "Ei, Lúcifer! Satanás, dos meus Infernos!"

Voz minha se estragasse, em mim tudo era cordas e cobras. E foi aí. Foi. Ele não existe, e não apareceu nem respondeu - o que é um falso imaginado. Mas eu supri que ele tinha me ouvido. Me ouviu, a conforme a ciência da noite e o envir de espaços, que medeia. Como que adquirisse minhas palavras todas; e fechou o arrocho do assunto. Ao que eu recebi de volta um adejo, um gozo de agarro, daí umas tranquilidades - de pancada. Lembrei dum rio que viesse adentro a casa de meu pai. Vi as asas. Arquei o puxo do poder meu, naquele átimo. Aí podia ser mais? A peta, eu querer saldar: que isso não é falável. As coisas assim a gente mesmo não pega nem abarca. Cabem é no brilho da noite. Aragem do sagrado. Absolutas estrelas! (:394).

A cena do (suposto) pacto de Riobaldo é, assim como toda a obra, repleta de ambiguidades, dúvidas e incertezas ${ }^{8}$. Nós não ficamos sabemos se ele vendeu sua alma ao diabo naquela noite, mas o fato é que, logo após o feito, Riobaldo, fortalecido, conquista (e recebe) de Zé Bedelo o posto de chefe. Nessa condição é que ele, apelidado de Urutu-Branco, vai liderar a perseguição e a incursão final contra Hermógenes e seu temível bando.

O enfrentamento entre os dois grupos vai acontecer em um arraial por nome Paredão, que, no fatídico dia do derradeiro embate, está deserto de moradores, mas repleto de jagunços (mais de trezentos), de ambos os lados. A batalha no arraial é sangrenta e dramática, especialmente o duelo corporal entre Diadorim e Hermógenes que resultou na morte dos dois. Quando vê a cena, Riobaldo é acometido de uma tonteira, uma embriaguez da alma que o leva para um outro plano existencial ("subi os 
abismos") até que, tempos depois, retorna e desperta com a notícia da morte de Diadorim - que ele já sabia mas não queria saber. A novidade e revelação vem na sequência quando Diadorim é despida para ser lavada e vestida. Diadorim é uma mulher?

Na sequência do livro, que já caminha para o final, Riobaldo, quando está retornando do Paredão, recebe a notícia de que Zé Bebelo se encontra em um lugar chamado Porto Passarinho, léguas acima de onde estava. Riobaldo não pensou duas vezes e foi ao encontro de seu antigo chefe. Bebelo, contente em rever o velho amigo, vai logo contando as novidades - diz que pretende deixar o sertão e se mudar para a cidade grande, "Mover com comércio, estudar para advogado" (:566).

Em determinado momento, Bebelo, exigindo atenção total de Riobaldo e sabendo dos tormentos que o assolam, aconselha que ele vá ao encontro de um sujeito por nome Quelemém para ter um esclarecimento definitivo sobre a questão que tanto lhe inquieta. Bebelo escreve um bilhete e recomenda a Riobaldo entregá-lo a Quelemém. Em maio, no tempo do algodão lâla, quando tudo fica branquinho na Jijuã - Vereda do Buriti Pardo, onde morava Quelemém -, Riobaldo finalmente encontra o seu futuro mestre e compadre: "Compadre meu Quelemém me hospedou, deixou eu contar minha história inteira. Como vi que ele me olhava com aquela enorme paciência - calma de que minha dor passasse; e que podia esperar muito longo tempo. O que vendo, tive vergonha, assaz. Mas por fim, eu tomei coragem, e tudo perguntei: - 'O senhor acha que a minha alma eu vendi, pactário?!’” (:567). Nota-se a ambiguidade da formulação - é simultaneamente uma pergunta (?) e uma afirmação (!). Quelemém, por sua vez, então lhe responde: “Tem cisma não. Pensa para adiante. Comprar ou vender, às vezes, são as ações que são sempre iguais" (:568).

Riobaldo encerra a narrativa confirmando a existência do dilema: "Amável o senhor me ouviu, minha idéia confirmou: que o Diabo não existe. Pois não? O senhor é um homem soberano, circunspecto. Amigos somos. Nonada. O diabo não há! É o que eu digo, se for... Existe é homem humano. Travessia" (:568).

Terminada a obra, a questão continua aberta, sem solução.

\section{Os violeiros}

Os dilemas existenciais tão bem descritos por Rosa não parecem habitar somente as páginas do romance. Durante minhas andanças pelo sertão mineiro, muitas vezes atravessando os mesmos locais por onde passaram os personagens da saga roseana, em diversos momentos reconhecia nas pessoas traços e características dos personagens de Rosa - na aparência, nos gestos, atitudes, hábitos e especialmente no modo de falar. $\mathrm{O}$ jeito de o povo falar, a oralidade e sonoridade das palavras e conversas, tão bem descritos por Carneiro (2015), eram uma interessante conexão entre o texto literário e a experiência etnográfica.

A sensação era de que o Grande Sertão havia criado como linguagem (por meio da narrativa escrita) um modo de ser e de pensar que eu encontrava vivo. A questão 
da ambiguidade do real, que ocupava Riobaldo do início ao fim do romance, aparecia, por exemplo, nos relatos dos violeiros quando me falavam sobre as origens, os modos de se tocar e se aprender viola. Durante o trabalho de campo, tive a sorte de conhecer e conviver com figuras como Minervino Guimarães, Martinho Rodrigues e Olegário Barbosa.

Os três velhos violeiros, infelizmente já falecidos, responsáveis pela maior parte do material aqui descrito e analisado, eram procedentes de uma mesma região, na zona rural do município de São Francisco, distante em torno de trinta quilômetros da sede. Minervino morava na vila do Angical, às margens do córrego do Angical, enquanto Martinho residia na Taboquinha, que ficava uns dez quilômetros morro acima. Já Olegário, que havia nascido na região da Taboquinha, morava em um bairro na periferia da cidade de São Francisco.

Martinho foi sem dúvida o mais próximo. Em parte do trabalho de campo, morei em sua casa, na Taboquinha. Martinho adorava contar histórias e lembrar dos casos antigos. Com 83 anos de idade, ele lembrava de sua juventude, contava com orgulho do seu trabalho como carapina. Falava das casas, dos carros de boi e até dos engenhos que construiu. Contava também sobre as folias que ele amava e que ajudou a levantar na "comunidade". Quando o conheci, vez por outra ele ainda acompanhava as folias quando estavam perto da sua casa. Sempre com a sua viola em punho, instrumento que passou a construir depois de deixar o serviço pesado de carapina, Martinho adorava contar causos e prosear sobre os mais diversos assuntos. Ele nos deixou em 27 de agosto de 2018, aos 97 anos.

Minha relação com Minervino, não tão íntima e próxima como a de Martinho, foi intensa e rendeu bons frutos. $\mathrm{O}$ contato com o violeiro iniciou-se quando passei a integrar a equipe do projeto "Celebrações e Saberes da Cultura Popular - Viola de 10 cordas", coordenado pelo Centro Nacional de Folclore e Cultura Popular (CNFCP/IPHAN). A intenção do projeto era elaborar um inventário da viola a partir da pesquisa etnográfica voltada para os processos de fabricação do instrumento, suas afinações e modos de tocar bem como para as narrativas e os contextos rituais e lúdicos de seu uso. Seu Minervino, que, além de tocador, era construtor de viola, foi um dos principais colaboradores dessa pesquisa. Nesse mesmo período, ele ainda participou do "PACA" (Programa de Apoio a Comunidades Artesanais - CNFCP/IPHAN), e, por causa das ações desse projeto, sua oficina de trabalho foi reconstruída e ampliada e Minervino, como mestre na arte e ofício de fazer viola, passou a receber, pelo período de seis meses, uma quantia para ensinar outras pessoas a construir viola. Seu Minervino veio a falecer em 2009, aos 81 anos $^{10}$.

Olegário Pereira Barbosa (que tinha o curioso apelido de Capeta, segundo ele, herdado de uns de seus tios) era um excelente violeiro, e lembro-me bem do dia em que o encontrei pela primeira vez. Foi em uma noite durante a dança de São Gonçalo que havia sido organizada para pagar a promessa de um devoto. A dança ocorreu no chão batido de uma rua da Sagrada Família, bairro popular da periferia de São 
Francisco, onde o próprio Olegário morava. Olegário era um excelente violeiro, dos maiores que vi tocar. Dono de uma enorme unha no dedo polegar que ele tratava com todo cuidado, era conhecedor de muitos "toques" de viola e de histórias de violeiros. Apesar de não ter tido muito contato com ele, já que veio a falecer em 2007, os encontros que tivemos foram marcantes, e eu sabia que estava diante de um homem de idade, que tinha vivido em um outro tempo. Um violeiro do tempo antigo com muito conhecimento e sabedoria.

\section{A viola}

O contato com esses (e com tantos outros) violeiros me fez perceber que a viola é um instrumento particularmente ambíguo: se, por um lado, é sagrada e abençoada, já que sua origem está associada ao nascimento de Jesus, à visita dos Reis Magos e às folias de reis, por outro, é um instrumento perigoso e cercado de tabus, narrativas e histórias de pacto envolvendo violeiros vivos e mortos, o demônio e locais como igrejas, cemitérios e encruzilhadas.

Para muitos devotos dos reis magos, que todo ano, entre 24 de dezembro e 6 de janeiro, participam das festividades em honra dos Santos Reis espalhadas e difundidas por todo o norte e noroeste de Minas Gerais, os três reis eram, além de pessoas de grande sabedoria e intuição, músicos e tocadores. Em diversos relatos que narram as origens das folias de reis, afora os conhecidos presentes - incenso, ouro e mirra -, fazse menção ao fato de os magos levarem para a viagem e visita que fizeram ao Menino Deus recém-nascido instrumentos musicais. Dentre os mencionados, a viola, ao lado da caixa e da rabeca (e, em alguns casos, o pandeiro) aparece como o mais recorrente.

Aí os Reis foram lá na gruta de Belém: chegou Brechó primeiro, Gaspar chegou segundo e Baltrazar chegou derradeiro. O primeiro que adorou Jesus foi o preto, ele chegou primeiro porque ele era o cabeça de folia. Ele que cantou o canto de reis, do nascimento de Cristo. Ele chegou primeiro, ajoelhou e cantou o nascimento de Cristo tudinho. Aí ele falou: "Vou cantar o nascimento de Cristo". Falou: "Vinde já meu Deus Menino / nasceu do meu coração / do varão nasceu a vara / da vara nasceu a flor / e da flor nasceu Maria / e de Maria o redentor / porque Jesus Cristo foi nascido / doze horas em verdade / porque Nossa Senhora pariu / Jesus Cristo na cidade". Agora ele chamou os outros e cantou, só com uma viola, uma rebeca e uma caixa. Aí agora é que foi aparecendo violão, esses tipos de coisa. Agora juntou os três e cantou, porque a folia nós canta é de quatro, né? Dois pra cantar e dois pra responder, mas a folia certa é três. (relato de Joaquim Batista da Silva, "Quinca Beiju", cabeça da folia dos irmãos Batista, São Francisco, 25/08/2005) ${ }^{11}$. 
Ao analisar comparativamente as narrativas sobre a origem da folia (Chaves 2014), percebe-se que, tendo como pano de fundo uma estruturação comum (em termo de personagens, ações, relações e sequências) e alguma margem para diferenciações (de ênfases, condensações e alargamentos de determinadas passagens, acréscimos ou supressões de detalhes), elas, no geral, coincidem em afirmar que os reis magos, quando chegaram à gruta em Belém, cantaram e tocaram para o menino Jesus. Tal canto, denominado saudação, ainda de acordo com essas narrativas, teria acontecido no princípio do mundo, originando assim a primeira folia de reis.

Dizem ainda que a dádiva oferecida a Jesus em forma de música foi recebida e que ele em troca teria abençoado os reis e os seus respectivos instrumentos musicais. É por essa razão que a viola, bem como a caixa e a rabeca (ou o pandeiro), é abençoada e sacralizada, conforme me explicou certa vez Minervino: "Dizem que a viola é abençoada né? Veio do princípio do mundo, a viola é abençoada, porque foi a viola que tocou fazendo a saudação do nascimento de Jesus" (entrevista com Minervino, 03/2004.

No decorrer de um giro de folia ${ }^{12}$, quando observamos os comportamentos, atitudes e o modo como as pessoas se relacionam com os instrumentos musicais, nota-se a centralidade da viola. Além de ser o instrumento mais adequado para o guia ou cabeça do grupo, a viola ainda é a base para o processo de afinação dos demais instrumentos. É a segunda corda do instrumento, chamada baixão, que oferece a base da tonalidade para todos os demais instrumentos, sendo a referência para o processo de afinação do conjunto. A viola, portanto, articula o plano mítico das narrativas acerca da viagem e visita dos reis magos ao plano da performance ritual, e a construção da sacralidade do instrumento parece estar relacionada à sua capacidade de estabelecer essas mediações. Isso, todavia, não esgota a complexidade, diversidade e pluralidade de significados a ela atribuídos.

Corre na região uma história de que o diabo era um exímio violeiro, dotado de uma habilidade inigualável para tocar e tirar som do instrumento. Uma dessas narrativas me foi relatada pelo próprio Minervino:

A história é isso, é porque o demônio chegou, era um homem, chegou tocando rio abaixo, tocando rio abaixo. Aí chegou na casa, aí o povo, todo mundo invocou com aquilo, né? $\mathrm{O}$ homem tocava aquele trem com aquela boniteza, e era um homem feio danado e tocando aquele tanto. Aí o povo invocou com aquele toque dele, que era bonito demais, mas aí na mesma hora botou a perder, botou ele a perder, o sujeito, né? Porque diz que o cão, o pé dele é redondo, você já ouviu falar, né? E o povo incutido com ele muito, porque ele tocando aquele tanto! Aí lá em pé, lá o menino foi, passou e rodeou ele pelas costas e olhou o pé dele, e o pé dele era redondo, aí o menino correu lá dentro na porta e falou: "O pé desse homem é redondo, parece o pé de cavalo, é redondo". Aí ele não gostou, não gostou, pegou a viola e tangeu no meio do terreiro, 
quando ele jogou a viola lá, caiu lá no chão era um braço de buriti, não era viola, era um pedaço do braço do buriti. Aí ele sumiu. (entrevista com Minervino, 03/2004).

Muitos elementos emergem dessa rica narrativa. Sem pretender esgotá-la, mencionaria primeiramente a conexão que se estabelece entre o tocador de viola (que até então não se sabia que era o diabo) e as pessoas que estavam ouvindo. $\mathrm{O}$ som da viola, de uma beleza ("boniteza") única, aparece inicialmente envolvendo e encantando as pessoas. No entanto, o que já parecia dúvida vira certeza quando um menino (esse ser "liminar" por excelência) descobre a verdade. Que o pé do homem é redondo, como o do cavalo. O homem que tocava lindamente a viola não era um homem. Era o... aí o restante da conversa já sabemos.

O curioso disso tudo é que a viola, anteriormente associada aos reis e à folia, agora é do capeta. Demônio, cão, pé de cavalo, o homem de que nos fala Minervino não nos faz lembrar das inúmeras passagens do Grande Sertão nas quais Riobaldo se questiona acerca da existência ou não do diabo? Longe de resolver os paradoxos e ambiguidades, ambas as narrativas parecem justamente potencializá-los, deixando abertura para dúvidas e incertezas.

E nós, como interpretar esse mundo que se move no terreno escorregadio das veredas, com suas misturas, indecisões e caminhos? Como entender um instrumento que é sagrado, do princípio de mundo e, ao mesmo tempo, do capeta? Seja como for, a viola, com a sua capacidade de conectar pessoas, narrativas, sons e silêncios, parece um bom exemplo do que Turner, em suas análises sobre processos de simbolização, denomina de "símbolo dominante" (Turner 2005 [1967])?

\section{Aprendizados: influência e parte}

Um dos assuntos que mais me intrigam enquanto antropólogo e etnógrafo é o da invenção, transmissão e circulação de conhecimentos. Ao acompanharmos algumas narrativas sobre como se aprende (e eventualmente como se ensina) a tocar viola, nos deparamos com verdadeiras teorias sobre a transmissão e circulação de conhecimentos, um interessante campo para a pesquisa etnográfica e comparativa (Barth 1987, 2002) ${ }^{14}$.

Em linhas gerais e assumindo o risco de simplificação, percebi que existem dois modelos locais para o aprendizado do instrumento: o primeiro e mais referenciado quando os violeiros explicam como aprenderam enfatiza a noção de influência, que pressupõe, entre outras coisas, um aprendizado processual, gradual e demorado; já no segundo, que, quando relembrado, é sempre no intuito de deslegitimar e acusar um "outro" violeiro, o aprendizado é, diferentemente do primeiro caso, imediato e repentino, resultado de um pacto - com o diabo ou com a alma de algum afamado violeiro falecido ${ }^{15}$. 
Em conversas com os violeiros, é comum que eles expliquem o aprendizado (incluindo o seu próprio) por meio da categoria influência. Ter influência é condição para alguém aprender um instrumento (e outras habilidades que envolvam algum grau de especialização), e não a ter é certamente um obstáculo ao aprendizado. Mas o que é a influência? Como podemos entender a categoria? De saída, percebe-se que o termo tanto se refere a um dom, que, em última instância, é herdado e inato ("uns têm e outros não têm"), quanto à capacidade de desenvolvimento de algumas habilidades aprendidas mediante observação, memorização, imitação e interpretação. Influência, portanto, parece ter uma dupla natureza: é tanto inata (herdada, natural, substancial) quanto adquirida (transmitida, aprendida, experimentada).

Em relação a esta última dimensão, os violeiros, quando explicam como aprenderam, contam que o aprendizado teve início com a observação de outros violeiros, em geral durante as folias. Nesses contextos festivos e devocionais, em que as pessoas se engajam em práticas coletivas e ritualizadas, os saberes e conhecimentos circulam no curso das ações e interações concretas (Brandão 1981, 1983) ${ }^{16}$. Nesse sentido, é comum dizerem que aprenderam sozinhos, sem professor. Seu Martinho, ao me explicar o conceito de influência, disse que era "tipo uma inveja" e em seguida arremata, "inveja boa", que surge quando uma pessoa se depara com alguém fazendo algo e ela sente vontade de também fazer.

O engajamento ativo do aprendiz em seu aprendizado - "essa inveja boa" que o impulsiona ao trabalho - é evidenciado no relato de Martinho quando nos conta como foi aprendendo a tocar viola:

Viola foi... eu peguei fazer uns trenzinho de pau, mesmo uns trenzinho meio à toa, e tem influência demais, aí depois eu mandei fazer uma violinha, o Juquinha Bicota, uma violinha miudinha e eu fui mexendo com ela, mexendo, mexendo, aprendendo um tiquinho...Pra gente começar a aprender a gente pega e arranja uma violinha e vai briquitando mesmo é em casa, caçando posição, pelejando pra aprender a afinar... porque ali você pega uma viola afinada e assunta tudo como é ali nas posição pra ir pondo as corda mais ou menos naquele rumo, aí ele vai aprendendo. Depois que aprende afinar, a gente vai caçando posição ali, aonde é que dá um assunto né? Assim a gente vai aprendendo. (entrevista com Martinho, 24/12/2004).

O aprendizado, na concepção de Martinho, é sempre um aprender, um aprendendo. Ou seja, trata-se de um verbo, uma prática contínua e sem termo. O desejo e a vontade, conjugados ao esforço pessoal de engajamento com o instrumento, no entanto, podem não ser suficientes se a pessoa não tiver "influência" (no primeiro sentido). Em última análise, se não tiver o dom, não adianta ir "mexendo", "briquitando" ou tentando afinar o instrumento que o aprendizado não vai fluir. Como 
uma vocação, uma dádiva que a pessoa traz de nascença (ou de berço como dizem), alguém só se torna de fato um bom violeiro se tiver o dom para tocar viola. A conjugação desses dois aspectos ou desses dois sentidos da categoria influência é que resulta no aprendizado por esse método. Nesse mesmo sentido, Olegário diz: "Aprendi de vê os outros tocar, vai guardando na memória aquilo e aprendendo. Porque em escola eu nunca fui, aprendi foi pela ideia mesmo" (entrevista com Olegário, 03/2005).

Desse modo, na concepção local, aprender um toque é um jogo duplo que envolve uma boa memória para guardar o som em suas linhas gerais e um domínio das mãos e do braço no manuseio do instrumento. Tocar viola, portanto, é um ato de engajamento entre corpos e materialidades. Entre o corpo do tocador e o da viola. O aprendizado acontece por meio dessas interações, da memória auditiva e das habilidades e técnicas corporais (Mauss 2003 [1935]). Sonoro, visual e corporal, o processo de aprendizado exige do tocador, além de uma apurada percepção auditiva, uma atenção aos seus gestos, expressões e atitudes. Podemos dizer que o corpo todo (e todos os sentidos) participa do aprendizado (Baily \& Driver 1992) ${ }^{17}$.

Como estamos vendo, os violeiros acreditam que aprender a tocar uma viola é o resultado de uma influência que o aprendiz tem e que aqueles que não conseguem aprender não têm. A influência é pessoal e intransferível. Uma pessoa sem influência, em princípio, nunca vai aprender a tocar viola. Contudo, isso pode ser contornado a partir dos ritos de pacto com o diabo ou com a alma de algum afamado violeiro falecido. São diversas as fórmulas e receitas de contratos desse tipo envolvendo violeiros vivos e violeiros mortos (ou o demônio) e locais como igrejas, cemitérios e encruzilhadas. Se, no primeiro método, o aprendizado é por influência, que como observamos, envolve o dom e, também, um longo e árduo trabalho, o segundo método implica um aprendizado repentino que se dá às custas da entrega (venda) da alma. Quando se referem a este último modo de aprendizado, dizem que o violeiro toca por parte.

Nenhum violeiro afirmou que ele próprio tocava por parte, mas todos se lembram de alguma pessoa - geralmente violeiros velhos e já falecidos ou que moram em locais distantes - que já tomaram parte. Novamente, é seu Olegário quem esclarece:

Eu conheci um que aprendeu, que ele não sabia tocar e foi pra encruzilhada e pegou parte com o demônio pra aprender a tocar. Ele foi pra encruzilhada e levou pinga, levou uma média de cachaça e pôs na encruzilhada e ficou lá. A viola tava desafinada. Daqui a pouco o demônio veio, estalou os dedo dele tudo, foi lá, bebeu a pinga, afinou a viola e falou: "Agora você pode tocar". Era a afinação violada, porque diz que a lindovina é do capeta também; o povo diz que foi ele que inventou. Aí ele saiu tocando essa lindovina, e aprendeu. Aí agora ele ficou por parte, né? Botava a viola parada lá, ia viajar e a viola tocava sozinha. Hoje em dia não sei se tem mais isso não, mas de primeiro tinha [...]. Agora eu nunca precisei não, graças a Deus, ave Maria, não tenho coragem de fazer isso 
não, moço! Eu quero que Deus me ensine, agora o demônio, não, Deus me livre. Agora a cruzinha a gente põe dentro da viola, porque quando tá saindo com folia as vezes tem gente que atrapalha a folia, agora a gente põe a cruzinha dentro da viola. (entrevista com Olegário, 03/2005).

A narrativa de seu Olegário é muito rica em detalhes e na descrição dos procedimentos e ritos que o violeiro empenhou para "tomar parte" ("pegar parte com o demônio"). Se, para Riobaldo, permanecia a dúvida a respeito do pacto (se foi ou não consumado), Olegário parece ter certeza de que o violeiro que conheceu fez efetivamente o trato com o capeta. O primeiro elemento a se destacar é o local onde vai acontecer o pacto - na encruzilhada. É para esse lugar que o postulante se dirige levando consigo, além da viola (desafinada), a cachaça a ser oferecida ao demônio. Interessante é notarmos que, antes de beber a pinga, pegar e afinar a viola, o demônio vai e estala os dedos do violeiro. Nesse momento, o violeiro adquire repentinamente uma aptidão corporal que é fundamental para alguém se tornar violeiro - ter os dedos moles. Os violeiros costumam dizer que um bom tocador deve ter os dedos leves, soltos e moles para poder tocar com agilidade e rapidez. A questão é que o desenvolvimento dessa habilidade corporal em geral demora e exige, como vimos, dedicação e paciência do violeiro. No entanto, o caminho escolhido é instantâneo e conduz de uma só vez a pessoa de um extremo (não saber tocar) ao outro (sai tocando).

A narrativa menciona ainda alguns conhecimentos importantes para alguém se tornar um violeiro, como a capacidade de afinar o instrumento e o domínio dos "toques" (que são temas instrumentais memorizados e executados pelos violeiros). No caso, o capeta é quem afina a viola (em uma afinação chamada de "violada", muito comum na região) e entrega o instrumento para o tocador que imediatamente já sai tocando a "lindovina", que é um "toque" difícil e muito apreciado. Outro elemento bem interessante no relato é quando diz que a viola após afinada pelo capeta nunca mais deixou de soar, mesmo estando parada e sozinha. Como entender que um instrumento pode tocar sozinho, sem tocador? Não seria o capeta o verdadeiro criador (e proprietário) de determinados "toques" e afinações ${ }^{18}$ ?

O aprendizado repentino que vimos ocorrer no relato do pacto com o capeta na encruzilhada também poderá acontecer de outro modo, em outros lugares e com outros participantes. Seu Henrique, um senhor espevitado e que não à toa tinha o apelido de "quente" (da família dos "quente") era cabeça de folia, rabequeiro, rezador e curador. Natural de uma localidade chamada Cedro, na beira do rio Pardo, do lado esquerdo do Rio São Francisco, Henrique tinha muita sabedoria e entendimento das coisas, inclusive as invisíveis. No relato a seguir, ele conta como um violeiro pode aprender com uma entidade chamada "rei dos tocador":

Agora eles têm outro dizer. Eu não sei por que nunca fiz, meter a mão dia de sexta-feira da paixão no adro da igreja e pedir pro rei dos tocador 
ensinar a tocar. Mas diz que a pessoa caga, urina de dor, quebra os osso da mão tudinho, dos dedo tudinho, pra adiante, pra trás, que a pessoa vira aquele mulambo... dizem. Pra lá já é rei dos tocador, porque lá dentro o maior mestre dos tocador já não é o capeta, porque o capeta não vai na igreja, né? Aí já é outra parte, né? Eu conheci um que meteu, ele diz que urinou na roupa e cagou de tanta dor, mas também quando saiu de lá, que a mão adormeceu os dedo dele, pegava os dedo dele, dobrava pra cá e pra lá. A viola dele era desafinada, mas a hora que ele batia o dedo tava afinada de ponta a ponta. (entrevista com Henrique Pereira dos Santos, violeiro, rabequeiro, guia de folia, morador de São Francisco, 03/2005).

A igreja aparece como um espaço sagrado, onde se pode estabelecer contato com o "rei dos tocador", uma figura que chega e, assim como o capeta, amolece as mãos e os dedos do aprendiz. O método parece o mesmo, mas Henrique faz questão de sublinhar que são "partes" diferentes, isso porque, como afirma, "o capeta não vai na igreja, né?".

Um assunto que emerge nos dois relatos é o da afinação. Acompanhando o relato de Olegário, lá o que ocorreu foi que o demônio pegou a viola do sujeito que foi fazer o pacto e afinou - a afinação, como faz questão de evidenciar, era a "violada". O curioso é que a viola desde então passou a tocar sozinha. A afinação vai reaparecer no relato de seu Henrique quando ele menciona que a viola do violeiro que foi à igreja tomar parte com o "rei dos tocador" não precisa mais ser afinada. Sempre que o tocador bate o dedo, ela já está pronta.

Uma última modalidade de aprendizado repentino, como os que temos visto, vai ser com violeiros já falecidos. Nesse caso, a invocação da alma desse violeiro será no local onde ele está enterrado, em geral um cemitério. Martinho é quem dá mais detalhes: "Diz que no cemitério que a pessoa sabia que tinha tocador muito bom, eles ia lá meia-noite sexta-feira da paixão pra pôr a mão na sepultura, que o defunto vinha pegar a mão da pessoa, que a pessoa ficava bom pra tocar, que os dedo amolecia tudo [...]. Mas esse negócio de parte, o povo falava isso, mas eu não sei como é esse trem não" (entrevista com Martinho, 24/12/2004).

Os três relatos dizem respeito a processos repentinos de aprendizado, todos por parte, mas enquanto no primeiro quem ensina é o capeta, no segundo é uma entidade chamada "rei do tocador" (que não ficamos sabendo ao certo se é uma entidade abstrata ou se é a alma de algum tocador em particular) e no terceiro é um violeiro já falecido. Os locais onde acontecem o aprendizado também variam: no primeiro é a encruzilhada; no segundo, a igreja; e no terceiro, o cemitério. $\mathrm{O}$ momento também parece variar - enquanto no primeiro caso não há especificação de dia e hora, nos outros dois se menciona a sexta-feira da paixão (à meia-noite ainda detalha o último) como a data propícia para fazê-lo. Apesar dessas diferenças, aqui 
somente anotadas, nos três relatos o amolecer dos dedos é um fator decisivo para o sucesso do aprendizado.

Ao final desta caminhada, em que percorremos veredas e encruzilhadas, adentramos em igrejas e cemitérios ao lado de foliões e violeiros, uma questão (a questão) permanece: como explicar a ambiguidade da viola? Como entender um instrumento que é ao mesmo tempo sagrado e do capeta? E se formulássemos essa questão para Riobaldo, como ele responderia?

\section{Considerações finais}

Em uma de minhas muitas visitas à casa de Seu Minervino, o indaguei sobre a questão do capeta e se era verdade que as pessoas tomavam parte com ele para aprender a tocar viola. Em um primeiro momento, Minervino foi enfático: "Esse negócio de tomar parte num existe não. Eu num acredito nisso não. Isso é bestagem do povo mais velho". Com o desenrolar da conversa e diante do meu insistente interesse pela questão, o saudoso violeiro afirmou que, apesar de não acreditar no capeta, ele existe. A princípio, não entendi bem essa resposta. Mas como pode uma coisa existir sem se acreditar nela?

Com o tempo, e a leitura de Grande Sertão: Veredas foi importante nesse sentido, percebi não haver contradição no pensamento de Minervino e que as coisas (no caso o diabo) podem existir independentemente de as pessoas acreditarem nela. O verbo acreditar, nesse sentido, não está relacionado à dimensão ontológica do ser (pois, de fato, como afirma, o diabo existe), mas sim à intencionalidade do sujeito que pode ou não se vincular (botar fé) a ele.

Nessa cosmológica do tudo é e não é, tudo está continuamente se transformando e se misturando, como a mandioca mansa que vira braba e a braba que vira mansa. Na percepção dos violeiros e, também, de Riobaldo, o real não está reduzido a pares antitéticos e excludentes, mas em um constante movimento de "deslizamento entre os polos" e "fusão de contrários", fazendo emergir novas possibilidades e "formas mais ricas de integração do ser" (Candido 1964:135).

O idioma é o da mistura, da ambiguidade e das margens, desse lugar (entre lugares) no qual persiste a ausência de diálogo - entre dominantes e dominados, elite e povo, oficial e popular, deus e diabo, letrado e iletrado, escrita e oralidade, campo e cidade, tradição e modernidade, etc. A saída será pelo caminho do meio, a terceira margem do rio, onde tudo flui? Será, pois? E as armadilhas, que vêm a reafirmar as desigualdades de nosso tempo?

Seja como for, seja por que for, parece que estamos diante de um modo de discurso que Michael Sells (1994) chama de "apofático" e que, para Velho, é "orientado na direção da coincidência dos opostos e da unidade e identidade pela graça" (Evdokimov apud Velho 2007:5). Graça essa que está impregnada de ambiguidades e contradições, como vimos ao longo destas páginas por meio dos questionamentos de Riobaldo e dos relatos dos violeiros. 
Religião e Sociedade, Rio de Janeiro, 40(2): 75-97, 2020

\section{Referências Bibliográficas}

BARTH, Fredrik. (1987), Cosmologies in the Making. A generative approach to cultural variation in inner New Guinea. Cambridge: Cambridge University Press.

BARTH, Fredrik. (2002), "An Anthropology of Knowledge". Current Anthropology, vol. 43, no 1: 1-18.

BAILY, John; DRIVER, Peter. (1992), "Spatio-motor thinking in playing folk blues guitar". The world of music, vol. 34, $\mathrm{n}$ - 3: 57-71.

BOLLE, Willi. (2004), Grandesertão.br: o romance de formação do Brasil. São Paulo: Duas Cidades: Ed. 34.

BRANDÃO, Carlos Rodrigues. (1981), Sacerdotes da Viola: rituais religiosos do catolicismo popular em São Paulo e Minas Gerais. Petrópolis, Vozes.

BRANDÃO, Carlos Rodrigues. (1983), "Os mestres da folga e da folia”. In: C. R. Brandão. Casa de Escola - cultura camponesa e educação rural. Campinas: Papirus.

CANDIDO, Antonio. (1964), "O homem dos avessos". In: A. Candido. Tese e antítese. São Paulo: Companhia Editora Nacional.

CARNEIRO, Ana. (2015), O povo parente dos buracos: sistema de prosa e mexida de cozinha. Rio de Janeiro: E-papers.

CHAVES, Wagner. (2009), A bandeira é o santo e o santo não é a bandeira: práticas de presentificação do santo nas Folias de Reis e de São José. Rio de Janeiro: Tese de Doutorado em Antropologia Social, MN/ UFRJ.

CHAVES, Wagner. (2014), "A origem da folia de reis na tradição oral: variações de um mito". In: H. Oliveira (org.). Mitos, Folias e Vivências. Rio de Janeiro: Mauad: Bapera.

CHAVES, Wagner e FONSECA, Edilberto. (2005), Sons de Couros e Cordas: instrumentos musicais tradicionais de São Francisco, MG. Rio de Janeiro: Iphan/CNFCP. (Sala do Artista Popular, 124).

CLIFFORD, James; MARCUS, George. (1986), Writting Culture: The Poetics and Politics of Ethnography. California: University of California Press.

DAMATTA, Roberto. (1993), "A obra literária como etnografia: notas sobre as relações entre literatura e antropologia”. In: R. DaMatta. Conta de mentiroso: sete ensaios de antropologia brasileira. Rio de Janeiro: Rocco.

LAPLANTINE, François. (2003), "Antropologia e literatura”. In: F. Laplantine. Aprender antropologia. São Paulo: Brasiliense.

MARCUS, George; CUSHMAN, Dick. (1982), "Ethnographies as texts”. Annual Review of Anthropology, no $11: 25-69$.

MARTINS COSTA, Ana Luisa. (2002), "Diadorim, delicado e terrível”. Scripta, vol. 5, no 10: 38-52.

MAUSS, Marcel. (2003 [1935]), "As técnicas corporais". In: M. Mauss. Sociologia e Antropologia. São Paulo: Cosac Naify.

OSORIO, Patrícia; PRADO, Gustavo. (2015), "A construção narrativa da alteridade: por um diálogo entre antropologia e literatura". In: J. Abonizio (org.). Pesquisa e produção do conhecimento no contemporâneo: rotinas e rupturas. Cuiabá: EdUFMT.

PALMEIRA, Moacir; CARNEIRO, Ana. (2013), "Antropologia e literatura”. Revista de Ciências Sociais, vol. $44, \mathrm{n}^{-}$2: 7-11.

PEREIRA, Luzimar Paulo. (2012), "As vicissitudes da fama: os dons divinos e os pactos demoníacos entre os tocadores de viola de dez cordas do norte e noroeste mineiro". Revista de Antropologia, vol. 55: 1047-1083.

ROSA, João Guimarães. (1984), Grande Sertão: Veredas. Rio de Janeiro: Nova Fronteira, 17ํㅡㄹ. SAMPAIO, Theodoro. (1906), O rio de São Francisco e a Chapada Diamantina, 1879-80. São Paulo.

SELLS, Michael. A. (1994), Mystical languages of unsaying. Chicago/London: The University of Chicago Press.

TURNER, Victor. (2005 [1967]). "Símbolos no ritual Ndembu”. In: V. Turner. Floresta de símbolos: 
aspectos do ritual Ndembu. Niterói: EdUFF.

TURNER, Victor. (2013 [1969]). "Liminaridade e communitas". In: V. Turner. O processo ritual: estrutura e antiestrutura. Petrópolis: Vozes.

VELHO, Otávio. (1995), "Religiosidade a Antropologia". In: O. Velho. Besta-Fera: recriação do mundo. Rio de Janeiro: Relume-Dumará.

VELHO, Otávio. (2007), "Epistrophê: do duplo vínculo às antinomias e de volta". Rever - Revista de Estudos da Religião, ano 7: 123-144.

\section{Vídeo consultado}

LYRA, Pedro Dacosta (dir.). (2005), Seu Minervino e a Viola Caipira. Produtora Cosmorama. Disponível em: https://www.youtube.com/watch?v=eDQg6qFjjy0. Acesso em: 15/07/2019.

\section{Entrevistas}

Entrevista com Henrique Pereira dos Santos, "Henrique Quente”, março de 2005.

Entrevista com Joaquim Batista da Silva, "Quinca Beiju”, 25 de agosto de 2005.

Entrevista com Martinho Rodrigues da Silva, 24 de dezembro de 2004.

Entrevista com Minervino Gonçalves Rodrigues Guimarães, março de 2004.

Entrevista com Olegário Pereira Barbosa, "Olegário Capeta", março de 2005.

\section{Notas}

1 Minha aproximação ao universo do vale do São Francisco e ao Grande Sertão: Veredas de Guimarães Rosa aconteceu simultaneamente. Em 2002, quando iniciava a pesquisa etnográfica que resultou em minha tese de doutorado (Chaves 2009), estava justamente terminando de ler o romance de Rosa. Ao mesmo tempo que lia as sagas de Riobaldo, reconhecia os lugares, as pessoas e a linguagem do grande sertão in loco, percorrendo ao lado dos foliões longos trajetos durante os seus giros rituais. Desde então, o texto me arrebatou de um modo que se tornou importante fonte no meu exercício de compreensão das múltiplas dimensões da realidade sertaneja.

2 Ao aproximar antropologia e literatura, penso em um movimento que se assemelha ao que Velho (1995) desenvolve ao relacionar antropologia e religiosidade. A pergunta que anima o diálogo que propõe entre o discurso religioso e o antropológico gira em torno do que este pode aprender com aquele ao abordar por exemplo a problemática dos dualismos (como a clássica oposição sujeito/objeto). Nessa visada, a religiosidade deixa de ser concebida como um "campo" (ou um objeto) a ser observado e analisável antropologicamente e passa a ser encarada como uma "perspectiva a partir da qual se tem algo a dizer sobre o conjunto da experiência humana" (Velho 1995:49). Levando a sério o discurso religioso como um modo de conhecimento e tratando-o simetricamente em relação ao discurso antropológico, Velho caminha em direção à uma antropologia da relação, ou do relacionamento, em que o homem não necessariamente ocupa o centro, se é que nessa ontologia relacional ainda faça sentido se falar em um centro. Assim como a religiosidade enquanto perspectiva contribui para a antropologia repensar algumas de suas problemáticas fundamentais, o mesmo podemos dizer em relação à literatura. É nesse intuito que o mergulho no texto (e na perspectiva) literário aqui proposto pode vir a iluminar determinadas questões etnográficas.

3 A edição de referência de Grande Sertão: Veredas é a 17ª̣, publicada em 1984 pela Editora Nova Fronteira, Rio de Janeiro.

4 Assim se refere Turner aos atributos das entidades liminares: "Os atributos de liminaridade, ou de personae (pessoas) liminares são necessariamente ambíguos, uma vez que esta condição e estas pessoas furtam-se ou escapam à rede de classificações que normalmente determinam a localização de estados e posições num espaço cultural. As entidades liminares não se situam nem aqui nem lá; estão no meio e entre posições atribuídas e ordenadas pela lei, pelos costumes, convenções e cerimonial" (Turner 2013:98).

5 A construção da imagem do sertão como o "outro" da civilização aparece, por exemplo, no relato de viajantes, como Theodoro Sampaio que, entre 1879 e 1880, em passagem pela região, comenta: "A princípio parece ter sido mesmo do interesse e do plano da Corôa fazer dessa região uma terra de ninguém, sem fé, sem lei e sem Rei. 
[...] Assim tudo se processou sem qualquer vislumbre do poder Real. Na terra desamparada da justiça açoitaramse criminosos à procura de uma vida nova. Fixaram-se aventureiros. E mesmo homens de bem, seduzidos pela liberdade que aí encontravam iam se deixando ficar fascinados pela possibilidade duma existência livre da interferência do governo" (Sampaio 1906:27).

6 Zé Bebelo, assim como Riobaldo, parece incorporar os paradoxos e ambiguidades de viver na "liminaridade", de se mover entre mundos e nos interstícios entre a civilização, a lei e a ordem e o "sistema jagunço". Fazendeiro e com pretensões políticas, Zé Bebelo, para levar progresso e civilizar o sertão ("por ordem naqueles sertões") deve combater o jaguncismo, que, segundo ele, é o responsável pelo atraso do sertão. Com o auxílio do governo, que financia e cede soldados para as suas incursões contra os bandos de jagunços, Bebelo deseja debelar o janguncismo e pavimentar a estrada do progresso na região. Ele segue firme em seu propósito até que um revés acontece em sua vida. Em uma das batalhas que se envolveu, é feito prisioneiro pelo grupo de Joca Ramiro, ao qual pertencia Riobaldo, Hermógenes, Ricardão e outros jagunços temidos. Bebelo é levado a julgamento e, em uma das passagens mais impressionantes do romance, é julgado por um tribunal de jagunços e finalmente absolvido graças à intervenção de Joca Ramiro em seu favor. Bebelo é então intimado a deixar o sertão e não voltar mais à região enquanto Ramiro vivo for. Seu sumiço perdura até que ele retorna para chefiar um bando de jagunços reunido para vingar a morte de Joca Ramiro, traído e morto por Hermóneges. A atuação de Zé Bebelo, desse modo, transforma-se ao longo da narrativa - de coronel e perseguidor de jagunços passa a líder de bando até finalmente se aposentar e deixar a liderança para Riobaldo.

7 Antonio Candido (1964), em sua reflexão sobre o Grande Sertão, defende a ideia de que a obra é um caso exemplar do que denomina de "princípio da reversibilidade". Tal princípio se manifesta através dos distintos planos e dimensões de ambiguidade nos quais a narrativa de Rosa está construída. De acordo com Cândido, seja no tratamento dado ao ambiente geográfico, aos tipos sociais, aos sentimentos e sexualidade dos personagens, seja na atenção concedida às reflexões em torno da existência (ou não) de deus e do diabo, Grande Sertão "compõe um deslizamento entre os pólos, uma fusão de contrários, uma dialética extremamente viva, que nos suspende entre o ser e o não ser para sugerir formas mais ricas de integração do ser. E todos se exprimem na ambiguidade inicial e final do estilo, a grande matriz, que é popular e erudito, arcaico e moderno, claro e obscuro, artificial e espontâneo" (Candido 1964:135).

8 Para uma análise do pacto no Grande Sertão: Veredas, remeto o leitor ao trabalho de Bolle (2004), especialmente o capítulo IV, intitulado "O pacto: esoterismo ou lei fundadora?".

9 Diadorim é uma personagem emblemática na obra de Rosa. Personificação da coragem e guerra, beleza e feminilidade, ela incorpora as ambivalências de ser uma mulher que, para se inserir na jacunçagem, se faz passar por homem. Diadorim, rebatizada Reinaldo, é filha(o) de Joca Ramiro, chefe de um grupo de jagunços morto por Hermóneges, cuja morte ela(e) pretende vingar. No decorrer da narrativa, Riobaldo se apaixona por Diadorim, e o desfecho do amor proibido entre os dois se dá de modo trágico ao final do romance quando a personagem é morta e, uma vez desnuda, tem a sua verdadeira identidade revelada. A pesquisadora Martins Costa (2002), em um texto sobre a personagem, defende a ideia de que é a ambiguidade existencial de Diadorim (ao mesmo tempo delicado e terrível, masculino e feminino) o que desperta e fascina Riobaldo.

10 Como desdobramento desse projeto, participei da organização de uma exposição na Sala do Artista Popular (SAP/CNFCP) sobre instrumentos musicais de São Francisco (Chaves e Fonseca 2005) e realizei a pesquisa e a produção do filme Seu Minervino e a Viola Caipira (Cosmorama 2005). Disponível em: https://www.youtube.com/ watch?v=eDQg6qFjjy0. Acesso em: 15/07/2019.

11 Cabeça é termo que nomeia a principal liderança dos grupos de folia, aquele que detém os conhecimentos dos preceitos rituais, que domina o repertório de cantos e conduz as performances nas mais diferentes situações. $\mathrm{O}$ relato de Joaquim é um bom exemplo do caráter inventivo e criativo que povoa as narrativas sobre a origem da folia. Joaquim sublinha que a diferenciação entre os três reis era marcadamente uma diferença racial - um dos reis era negro e os outros dois brancos. A singularidade de sua narrativa quando relacionada a outras está em dizer que foi justamente o rei negro quem chegou primeiro para saudar o menino Jesus cantando o "nascimento de Cristo", que, dentre as passagens cantadas por uma folia, é a mais valorizada. Durante a pesquisa, estive com ele uma única vez, em sua casa, quando me concedeu essa entrevista. Embora estivesse morando na cidade de São Francisco, a origem de Joaquim era de um lugar por nome Buriti do Meio, um território de negros e que hoje abriga uma importante comunidade quilombola.

12 Giro é uma categoria local para se referir ao processo ritual da folia que se realiza por meio do deslocamento de um grupo de tocadores e cantadores (chamados foliões) por um território durante um período de tempo (variável, mas que pode chegar a doze dias seguidos), com vistas a efetuar um conjunto de visitas às casas dos devotos e a lugares como igrejas, cemitérios, capelas, currais e roças. Durante as visitas, os foliões, mediadores entre o santo e as pessoas, abençoam os locais e os que lá vivem (ou as almas dos que já se foram) em troca de donativos (dinheiro, 
comida, bebida e outros bens) que podem ser consumidos no local ou reunidos e posteriormente utilizados na preparação das festividades que marcam o encerramento daquele giro. Na maior parte das vezes, a motivação de fundo para a realização de um giro é o cumprimento (pagamento) da promessa de algum(a) devoto(a), sendo justamente da casa dele(a) que a folia inicia e termina a sua jornada ritual.

13 Em suas reflexões sobre os significados dos símbolos em contextos de ação ritual, Turner chama a atenção para a existência, em todo processo social, de determinadas formações (que podem ser objetos, gestos ou mesmo eventos) diante das quais muitas coisas e ações são representadas. Tais formações ou "símbolos dominantes", como denomina, se inserem na dinâmica coletiva e se associam a determinados papéis rituais e relações sociais, evocando ainda valores fundamentais para um dado grupo. De acordo com o antropólogo: "os símbolos dominantes são encarados não meramente como meios para o cumprimento dos fins confessos de um dado ritual, mas também e com maior importância, se referem a valores considerados fins em si mesmos, que dizer, valores axiomáticos" (Turner 2005:50). Outra propriedade dos "símbolos dominantes" evidenciada por Turner é a capacidade de condensarem em uma única formação muitos significados, revelando seu caráter polissêmico e sua multivocalidade. Fazendo uso da ideia de "símbolo dominante" de Turner para pensarmos o caso da viola e observando os empregos do instrumento nos contextos rituais, bem como acompanhando as narrativas em torno do seu aprendizado e origem, percebe-se como ela reúne em torno de si, além de um conjunto de ações significativas, muitas representações, algumas divergentes e antagônicas. Ademais, ainda com Turner, não podemos aventar a hipótese de que é justamente nessa ambivalência que reside a força e a potência da viola enquanto um "símbolo dominante" nos contextos pesquisados?

14 Para Barth (2002), o conhecimento (termo que usa para se referir aos sentimentos, atitudes e informações, habilidades, conceitos e classificações) é o que permite a uma pessoa interpretar e agir no mundo, experimentando e compreendendo os eventos, as situações e os acontecimentos. Evidenciando o caráter distributivo e a variação de modos como os conhecimentos circulam entre os membros de uma coletividade - presente em determinadas pessoas, ausente em outras -, Barth vai se interessar justamente pelos processos e relações que afetam sua distribuição. Desse modo é que, em sua proposta de uma "etnografia comparativa do conhecimento" (ou "antropologia do conhecimento"), este é analiticamente abordado em três planos: o conteúdo ou "corpus substantivo" que contém asserções substantivas e ideias sobre aspectos do mundo; os modos de circulação ou "meios comunicativos" (palavras, símbolos, gestos, ações, etc.); e as relações sociais instituídas (a "organização social”) no interior das quais circula. Esses aspectos, separados do ponto de vista analítico, todavia, na prática, nas situações concretas, como bem lembra o autor, estão relacionados e interdependentes. Assim, discutir as formas e meios de transmissão (o como se transmite) inevitavelmente nos conduz aos conteúdos (o que se transmite) e às relações sociais nas quais os saberes, atitudes, habilidades, competências e técnicas circulam. A perspectiva de Barth abre um caminho para pensarmos os conhecimentos como coisas em movimento, cuja existência está relaciona ao modo como fluem e circulam no tempo-espaço. Seguindo essas indicações e aproximando-as do nosso caso etnográfico, a pergunta central a se fazer não é tanto o que é ser um violeiro e sim como alguém se torna um violeiro - com quem, como e quais circunstâncias se aprende (ou não).

15 Remeto o leitor ao interessante trabalho de Pereira (2012) sobre a construção da reputação de violeiros a partir de disputas engendradas por relatos sobre pactos demoníacos. O contexto etnográfico no qual Pereira realizou sua pesquisa e aspectos do material que apresenta são próximos ao que estamos vendo, embora as respectivas análises apontem para distintos caminhos interpretativos.

16 Em seus estudos sobre os processos de transmissão e circulação de conhecimentos no interior de equipes rituais associadas à religiosidade popular, como congados e folias de reis, Brandão $(1981,1983)$ enfatiza, por um lado, a recorrente presença, na organização desses grupos, de posições destinadas às crianças, que, no decorrer do tempo, são estimuladas a uma gradual ascensão na hierarquia desses coletivos, desempenhando papéis cada vez mais complexos e especializados, e, por outro, que os saberes nesses contextos fluem por intermédio das vivências práticas e da participação nesses ritos, prescindindo, portanto, de situações mais formalizadas de ensinoaprendizagem como as que se encontram na educação escolar.

17 Baily e Driver (1992), em um interessante estudo sobre a guitarra no blues, dizem que o componente central da cognição musical não deve ser buscado nos aspectos ergonômicos (que se relaciona com as capacidades e limitações dos fatores humanos), e sim no que denominam "pensar espaço-motor" que se dá na interação entre os movimentos físico-corporais dos tocadores e a morfologia dos instrumentos. Nessa perspectiva, a produção sonora e a cognição musical relacionam-se tanto ao corpo humano quanto ao corpo do instrumento e ao espaço, e é nessa interação que o fazer e o pensar musical se realizam. Ao observar como, na guitarra de blues, a disposição das notas pelas seis cordas do instrumento possibilita e incentiva determinados modos (arranjos) de se tocar, eles relativizam a própria centralidade da dimensão sonora como sendo o meio principal de pensamento e cognição musical: "A hipótese de que esse arranjo estimula o pensamento espacial sugere que os padrões musicais são 
lembrados e executados não apenas como padrões auditivos, mas como sequências de padrões de movimento que têm repercussões visuais, cinestésicas, táteis e auditivas" (no original: "The hypothesis that this arrangement encourages spacial thinking suggests that musical patterns are remembered and executed not solely as aural patterns but as sequences of moviment patterns which have visual, kinaesthetic, tactile, as well as auditory repercussions").

18 A afinação "violada" (ou "natural"), cujas cordas, enumerando as notas relativas de baixo para cima, correspondem ao "mi-si-sol-re-la" respectivamente, e o "toque" denominado "lindovina" são muito comuns e populares nas localidades que se situam à margem direita do São Francisco, como na Taboquinha, Angical e outras. A associação que seu Olegário faz deles com o capeta, todavia, me pareceu até certo ponto incomum e não encontrei em outros relatos. Um assunto que merece aprofundamento em outra ocasião.

Submetido em: 08/08/2019

Aceito em: 09/07/2020

Wagner Neves Diniz Chaves* (wagnerchaves03@gmail.com)

* Professor do Departamento de Antropologia Cultural (DAC) e do Programa de Pós-Graduação em Sociologia e Antropologia (PPGSA) da Universidade Federal do Rio de Janeiro (UFRJ), Rio de Janeiro, RJ, Brasil; Pesquisador do RISU (Núcleo de Estudos "Ritual, Etnografia e Sociabilidades Urbanas"); Doutor em Antropologia Social pelo Programa de Pós-Graduação em Antropologia Social do Museu Nacional da UFRJ. 


\section{Resumo:}

\section{“Tudo é e não é": paradoxos e antinomias no pensamento de Riobaldo e no imaginário de violeiros do vale do São Francisco, norte de Minas Gerais}

artigo explora as correspondências simbólicas de um personagem de Guimarães Rosa com o universo dos violeiros no vale do São Francisco. O texto chama a atenção para a relatividade e ambivalência de nossas categorias de pensamento, explorando a cultura sertaneja tal como Rosa a constrói na biografia do ex-jagunço Riobaldo e de outros personagens. Sugere-se que o universo sertanejo "é um campo aberto de possibilidades", servindo como inspiração para vislumbrarmos muitas conexões com o contexto etnográfico. $\mathrm{O}$ dilema da existência ou não do diabo, que ocupa as preocupações de Riobaldo, é confrontado com a ambivalência simbólica de um instrumento musical, a viola, associada tanto a Jesus e aos Reis Magos quanto ao mal e ao próprio demônio.

Palavras-chave: Antropologia e Literatura; Grande Sertão: Veredas; Viola e Violeiros; Paradoxos e Antinomias

\section{Abstract:}

\section{"Everything is and is not": paradoxes and antinomies in Riobaldo's thought and in the imaginary of violeiros in the São Francisco valley, northern Minas Gerais}

The article explores the symbolic correspondences of a character of Guimarães Rosa with the universe of "violeiros" in the São Francisco valley. The text draws attention to the relativity and ambivalence of our categories of thought, exploring the country culture as Rosa constructs in the biography of ex-jagunço Riobaldo and other characters. The article suggests that the backwoods universe embodied in characters from the Rosean novel "is an open field of possibilities", serving as inspiration for us to glimpse many connections with the ethnographic context The dilemma of the existence or not of the devil, which occupies Riobaldo's concerns, is comparatively confronted with the symbolic ambivalence about a musical instrument, the viola, associated by the guitarists with both Jesus and the Magi as well as evil and demon himself.

Keywords: Anthropology and Literature; Grande Sertão: Veredas; Viola and Violeiros; Paradoxes and Antinomies 
